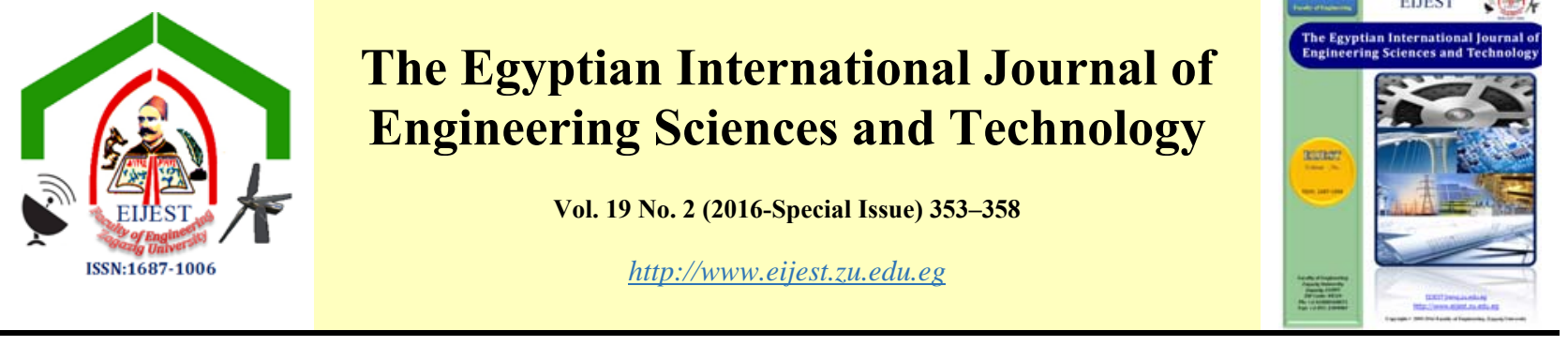

\title{
Change Detection of Manzala Lake Using Remote Sensing and Geographic Information System
}

\author{
H. Hossen ${ }^{a}$ and A. Negm ${ }^{b}$ \\ ${ }^{a}$ Ph.D. Student, Department of Environmental Engineering, Egypt-Japan University of Science and Technology E-JUST, P.O. Box 179, New Borg \\ El-Arab, Alexandria, Egypt \\ ${ }^{b}$ Head of Natural Resources Lab., Environmental Engineering, Egypt-Japan University of Science and Technology E- JUST, P.O. Box 179, New \\ Borg El-Arab, Alexandria, Egypt (Seconded from Faculty of Engineering, Zagazig University, Zagazig, Egypt)
}

\begin{tabular}{|c|c|}
\hline ART I CLE I N FO & A B S T RA C T \\
\hline $\begin{array}{l}\text { Article history: } \\
\text { Received } 31 \text { May } 2016 \\
\text { Accepted } 9 \text { July } 2016 \\
\text { Available online } 11 \text { July } \\
2016 \\
\end{array}$ & $\begin{array}{l}\text { Change detection in land use and land cover is one of the most important indicators } \\
\text { of global and regional environmental sustainability. In this paper, the maximum } \\
\text { likelihood supervised classification is applied to subsets of the Landsat TM, ETM+ } \\
\text { and OLI/TIRS images acquired on } 1984,1998 \text { and } 2015 \text {, respectively to monitor }\end{array}$ \\
\hline $\begin{array}{l}\text { Keywords: } \\
\text { Manzala Lake } \\
\text { Sustainability } \\
\text { Water bodies } \\
\text { Image Processing } \\
\text { Remote Sensing/GIS }\end{array}$ & $\begin{array}{l}\text { changes in Manzala Lake. Manzala Lake is the largest natural lake in Egypt, it is } \\
\text { located between longitudes } 31^{\circ} 45^{\prime} \text { and } 32^{\circ} 22^{\prime} \text { E and latitudes } 31^{\circ} 00^{\prime} \text { and } 31^{\circ} 35^{\prime} \\
\text { N. Six classes are detected including sea water, lake water (water bodies), floating } \\
\text { vegetation, Islands, sand bar and urban, and agriculture. ERDAS IMAGINE and } \\
\text { ArcGIS software are used in this study for processing of the images and managing } \\
\text { the database of each image. The results showed that the water bodies of the lake } \\
\text { decreased by } 57.06 \%(47,419.1 \text { ha), while floating vegetation and islands area } \\
\text { increased mostly by the same amount during the period from } 1984 \text { to } 2015 \text {. This } \\
\text { increase in floating vegetation is due to the discharge of agriculture wastes and } \\
\text { municipal wastes in the lake without adequate treatment. The sea water has minor } \\
\text { changes during the period of study. The agriculture area increased by } 28.57 \% \\
\text { (19,285.6 ha), while the sand bar and urban area decreased mostly by the same } \\
\text { amount during the period from } 1984 \text { to } 2015 \text {. The future prediction was conducted } \\
\text { using the annual rate of change over the next } 15 \text { years, resulted from this } \\
\text { prediction that the water bodies of the lake will be reduced by } 84.67 \% \text { ( } 70,363.85 \\
\text { ha), and this decrease leads to a negative impact on fisheries and the environment. } \\
\text { The results of this study shall help the decision-makers to take the necessary } \\
\text { measures to reduce the environmental risk and maintain the lake in order to sustain } \\
\text { the lake water area against further reduction. }\end{array}$ \\
\hline
\end{tabular}

\section{Introduction}

Change detection in land use and land cover

* Corresponding author. Tel.:+20-1007767223; fax: +20-34599520

E-mail address: hickmat.abdullah@ejust.edu.eg.
(LULC) is a key indicator to assess the environmental impacts. Change in land use and land cover is one of the most important factors that affect ecosystems, whether terrestrial or aquatic. Change in 
land use and land cover, as one of the key driving forces of global environmental change, is essential to the study of sustainable development [1]. To ensure the sustainable management of natural resources, it is our duty to monitor and control the processes of change in land use and land cover [2]. The spatial and temporal distribution of land use and land cover using satellite images is very important to understand and explain the phenomenon of global environmental change. Change in land use and land cover leads to the impact on the socio-economic, biological, climatic and hydrological systems [3]. Great concern about changes in the size and quality of many of the world's wetlands has arisen mainly as a result of increased urban development and agricultural development [4]. It is expected that Manzala Lake has some changes due to the discharge of agriculture wastes and municipal wastes in the lake without adequate treatment. Six main drains use to flow into Lake Manzala and affect its water quality. Drainage water contributes about $98 \%$ of the total annual inflow to Lake Manzala [5]. The discharge of agriculture wastes and municipal wastes in the lake without adequate treatment caused an increase in floating vegetation and decrease in water bodies. To learn about the changes that occur in land use and land cover somewhere, it is necessary to study the place at different times [6]. Remote sensing is used on a large scale to achieve an effective way in terms of cost to detect the changes in land use and land cover over wide geographic areas [7]. Satellites are working to provide a wide range of data to somewhere in the different time periods.

Change detection in land use and land cover is one of the most important key issues to monitor the environment change and natural resource management. Change detection in land use and land cover is an important factor to understand the interaction and the relationship between human activities with the environment. Change detection in land use and land cover across spatial and temporal scales is indispensable to achieve sustainable environmental management [8]. Classification and mapping the types of land use and land cover accurately is one of the important issues to support the sustainable management of natural resources. To understand how the impact of land use and land cover on ecosystems, it is necessary to provide information on what changes occur and where and when they occur, and the rates at which they occur, and the physical and social forces that drive these changes [9]. To explore the change in land use and land cover with high accuracy we always need to develop a classification system for the entire region, and the division of all objects into different classes according to the requirements of the study [10]. Classification of land use and land cover makes it easy to conduct statistical processes to detect the change from one category to another.

The aim of this study is to provide an accurate estimate of the land use and land cover in Manzala Lake to the decision maker to take the necessary measures to reduce the environmental risk and maintain the environment and access to sustainable development. There are many techniques to classify the images and detect the change, in this study we used Post-Classification Comparison technique because it has a high accuracy and the ability to avoid digital problems resulting from the difference in the sensor and the atmosphere is unlike the rest of the techniques. Post-Classification Comparison was used to detecting the change in the Sea water, lake water, Floating vegetation, Islands, Sand bar and urban, and Agriculture during periods 1984, 1998 and 2015. Accuracy was determined to detect the change in land use and land cover by calculating the classification accuracy for each image using an error matrix.

\section{Description of Study Area}

Manzala Lake is one of the most vulnerable lakes and is the largest natural lake of the Egyptian northern lakes along the Mediterranean coast. Geographically, it is located between longitudes $31^{\circ}$ $45^{\prime}$ and $32^{\circ} 22^{\prime} \mathrm{E}$ and latitudes $31^{\circ} 00^{\prime}$ and $31^{\circ} 35^{\prime} \mathrm{N}$.

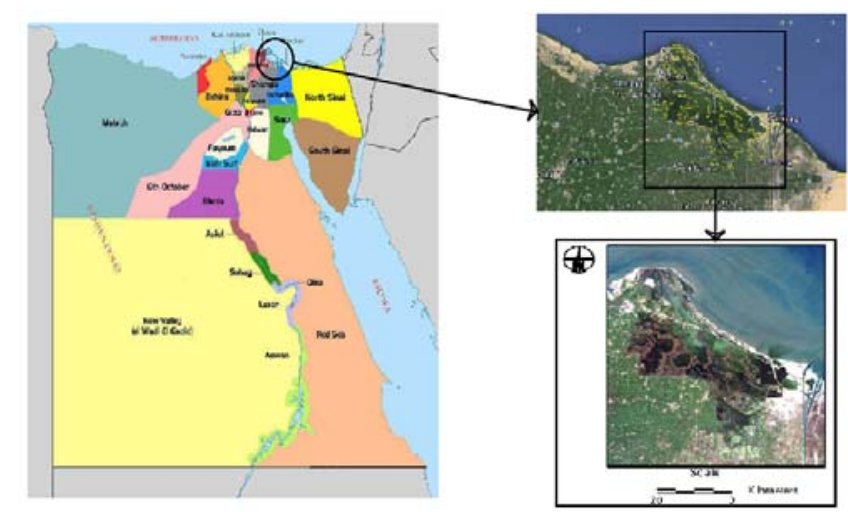

Fig. 1. Location of the study area of Manzala Lake

The lake is bordered by the Mediterranean Sea to the north and the North-East, Suez Canal to the East, Dakahlia and Sharkia governorates to the South and Damietta Branch of the Nile to the West (see Fig. 1). The surface area of Manzala Lake is about 1,471.92 
$\mathrm{Km}^{2}$. The lake is shallow, ranging from 0.7 to $1.5 \mathrm{~m}$ in depth. Manzala Lake linked to six drains through the southern and western shores [5]. Water bodies of the lake are mainly affected by the growth and creeping of floating vegetation, leading to a decrease in these bodies, and, therefore, the negative impact on environmental sustainability. To reach sustainable development should be established mechanisms to monitor and control the growth and creeping those floating vegetation.

\section{Data and Methodology}

Landsat Thematic Mapper (TM), Enhanced Thematic Mapper Plus (ETM+) and Operational Land Imager and Thermal Infrared Sensor (OLI/TIRS) images with $30 \mathrm{~m}$ ground resolution acquired on 1984, 1998 and 2015, respectively have been used to detect the change in Sea water, lake water, Floating vegetation, Islands, Sand bar and urban, and Agriculture, from 1984 to 2015. These images were downloaded from USGS Earth Explorer. The topographic maps owned by the Central Agency for Public Mobilization and Statistics at a scale of 1: 50,000 have been used to field investigations. Image processing and detecting the changes in land use and land cover were performed by the aid of the use of ERDAS 9.1 and ArcGIS 9.3 software. The study and analysis of the maps that were obtained for the detection of the change in the surface area of the lake water during previous periods of time and to predict the future.

\subsection{Image pre-processing}

Geometric correction of the images has been done using ERDAS 9.1 program through using of first order polynomial. The order of transformation is the order of the polynomial used in the transformation. The resampling processes of the images were carried out by using the nearest neighbor method. The nearest neighbor method does not change the cell values of the image and thus it is suitable before the classification process in addition to being easy to account and fast in use [11]. All images were registered at the same projection system (UTM, WGS 84).

\subsection{Image Classification}

In this study, a supervised classification technique was applied to subsets of the Landsat Thematic Mapper (TM), Enhanced Thematic Mapper Plus $(\mathrm{ETM}+)$ and Operational Land Imager and Thermal Infrared Sensor (OLI/TIRS) images acquired on
1984, 1998 and 2015, respectively. Supervised classification technique can avoid digital problems resulting from the difference in the sensor and the atmosphere. Supervised classification techniques contain three methods (maximum likelihood classification, minimum distance classification, and mahalanobis distance classification) and most accurate method is a maximum likelihood classification method [11]. A maximum likelihood supervised classification was applied in this study to monitor changes in Manzala Lake.

\subsection{Land use and land cover}

Land use and land cover is one of the most important natural resources. Water bodies and particularly, lakes are considered one of the most important components of the land cover. Lakes work to meet the community demand for food where it has Fisheries. Lakes exposed to environmental changes threaten the sustainability of those lakes, and thus there should be a monitoring and control mechanisms of those changes. Remote sensing is one of the most important mechanisms of monitoring to detect changes at different time periods.

\subsection{Change detection analysis}

Change detection determines the place and the amount of change in a certain land cover at different times. Most of the change detection techniques rely on images classification, whether supervised classification or unsupervised classification. Accuracy assessment of change detection depends on the accuracy of images classification, and classification with high accuracy gives high accuracy in the detection of change. In this study, postclassification comparison technique was applied to subsets of images on 1984, 1998 and 2015, respectively to monitor changes in Manzala Lake.

\section{Results and Discussion}

\subsection{Classification accuracy assessment}

Accuracy is the degree of confidence, defined as the degree of convergence between the results and the truth. To evaluate the classification accuracy, should be compared map of land use and land cover with reference data. To obtain a high accuracy of the classification of a certain category, there must be proportionality between the number of samples to that category and type and size of that category. If the study area exceeded about $500 \mathrm{~km}^{2}$ or exceeded the 
number of categories of 12 , it should be at least 75 100 samples taken in the same category [12].

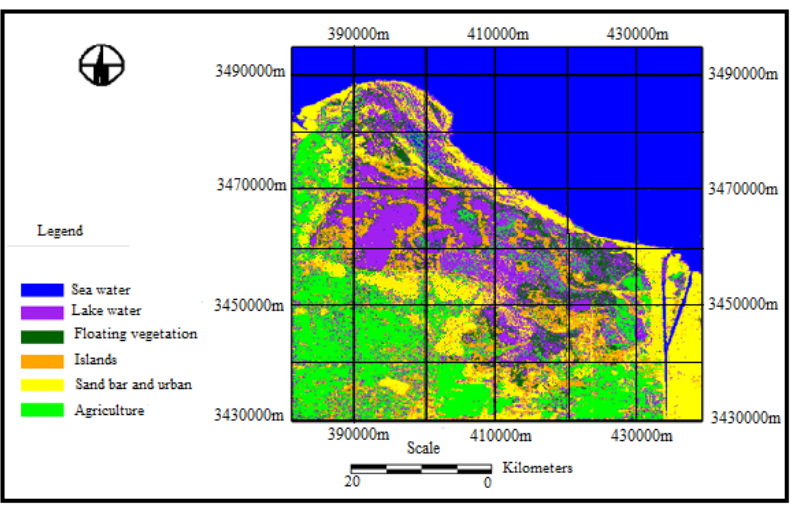

Fig. 2. The 1984 classified image

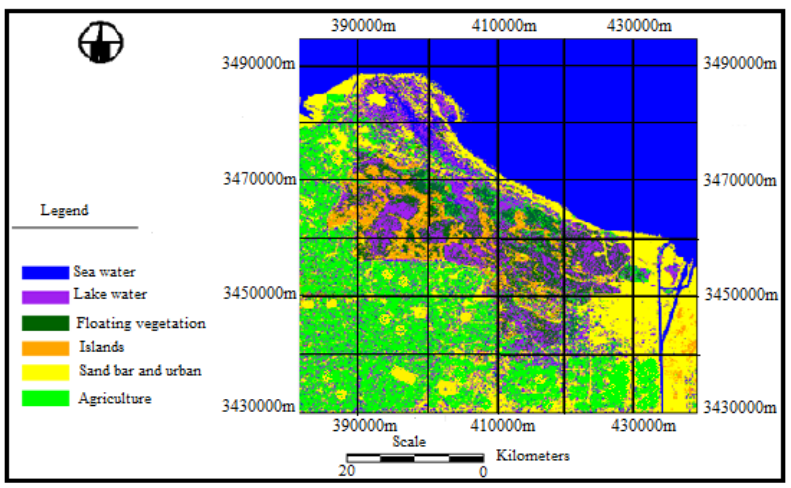

Fig. 3. The 1998 classified image

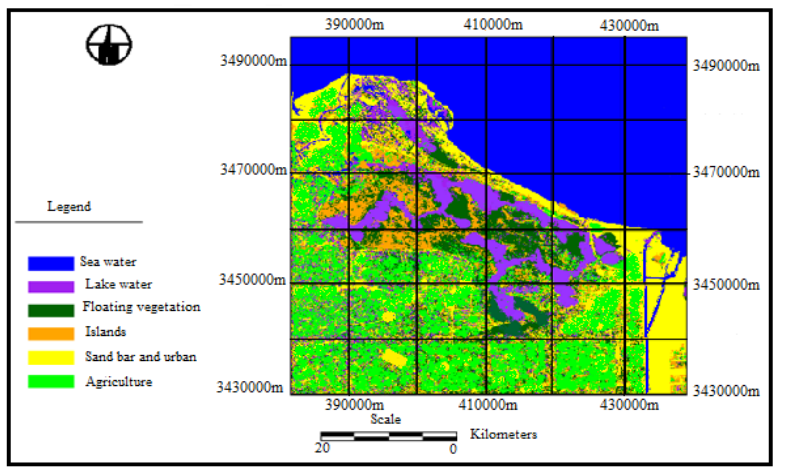

Fig. 4. The 2015 classified image

For accuracy assessment to images classification, there are two methods error matrix and Kappa coefficient. In the error matrix, the results of classification are compared to the real information on the surface of the earth, and the strength of error matrix is that it determines the nature of the errors as well as quantities. The overall accuracy of the classification is calculated by dividing the total number of the correct pixel by the total number of all pixels. There are two indicators of accuracy often mentioned with the overall accuracy. They are the user's accuracy and the producer's accuracy. The user's accuracy refers to the possibility that the pixels on the image represent that category on the ground [13]. The producer's accuracy is defined as the probability of correctly classified pixels and is used primarily to determine the extent of the area that can be classified [13]. The Kappa is a multi-discrete variables method used to assess the accuracy of classification maps. It is computed from the error matrix and implemented over the classification based on the data reference [14]. The overall accuracy for the classification of the captured images in 1984, 1998 and 2015 are $83.67 \%, 86.33 \%$, and $89.33 \%$ respectively. Figs. 2, 3 and 4 shows the classified images using the maximum likelihood classification method.

\subsection{Change detection analysis}

Change detection in the Manzala Lake in the period from 1984 to 2015 indicates that there is deterioration in the water bodies of the lake due to increased area of the floating vegetation. The results showed that the total area of the study area is about 379516.1 ha. Table (1) and Figure 5 show the change in each category during the three periods.

Table 1. The land cover changes (ha) in 1984, 1998 and 2015

\begin{tabular}{|l|c|c|c|}
\hline \multicolumn{1}{|c|}{ Class } & $\begin{array}{c}\text { Area in } \\
\mathbf{1 9 8 4} \text { (ha) }\end{array}$ & $\begin{array}{c}\text { Area in } \\
\mathbf{1 9 9 8} \text { (ha) }\end{array}$ & $\begin{array}{c}\text { Area in } \\
\mathbf{2 0 1 5} \text { (ha) }\end{array}$ \\
\hline Sea water & 119608 & 120221.6 & 120024.7 \\
Lake water & 83107.3 & 64192.4 & 35688.2 \\
Floating vegetation & 22436.6 & 38809.9 & 58505.5 \\
Islands & 41647.9 & 44063.1 & 53068.6 \\
Sand bar and urban & 45211.3 & 34023.3 & 25438.5 \\
Agriculture & 67505 & 78205.8 & 86790.6 \\
Total area & 379516.1 & 379516.1 & 379516.1 \\
\hline 35 \\
30 \\
25 \\
20 \\
15 \\
10 \\
5
\end{tabular}

Fig. 5. Land cover for the study area in 1984, 1998 and 2015

In the entire period from 1984 to 2015, water bodies of the lake decreased by $47,419.1$ ha $(57.06 \%)$, while floating vegetation and Islands area increased mostly by the same amount (see Table 2). 
Assuming a linear trend, the future change can be predicted as shown by Table (3). Similarly, Fig. 6 shows projected area of each category in the year 2030 .

Table 2. The lands cover changes (ha) in 1984 and 2015 and the average of change per year

\begin{tabular}{|l|c|c|c|c|}
\hline \multicolumn{1}{|c|}{ Class } & $\begin{array}{c}\text { Area in } \\
\mathbf{1 9 8 4} \\
\text { (ha) }\end{array}$ & $\begin{array}{l}\text { Area in } \\
\mathbf{2 0 1 5}(\mathbf{h a})\end{array}$ & $\begin{array}{l}\text { Total } \\
\text { Change } \\
\text { (ha) }\end{array}$ & $\begin{array}{l}\text { Change/ } \\
\text { year } \\
\text { (ha/year) }\end{array}$ \\
\hline Sea water & 119608 & 120024.7 & 416.7 & 13.44 \\
Lake water & 83107.3 & 35688.2 & -47419.1 & -1529.65 \\
Floating vegetation & 22436.6 & 58505.5 & 36068.9 & 1163.51 \\
Islands & 41647.9 & 53068.6 & 11420.7 & 368.41 \\
Sand bar and urban & 45211.3 & 25438.5 & -19772.8 & -637.83 \\
Agriculture & 67505 & 86790.6 & 19285.6 & 622.12 \\
Total area & 379516.1 & 379516.1 & --- & --- \\
\hline
\end{tabular}

Table 3. Projected Land cover area in 2030

\begin{tabular}{|c|c|c|}
\hline Class & $\begin{array}{c}\text { Rate of change } \\
\text { per year } \\
\text { (ha/year) }\end{array}$ & $\begin{array}{c}\text { Area in } 2030 \\
\text { (ha) }\end{array}$ \\
\hline $\begin{array}{l}\text { Sea water } \\
\text { Lake water } \\
\text { Floating vegetation } \\
\text { Islands } \\
\text { Sand bar and urban } \\
\text { Agriculture } \\
\end{array}$ & $\begin{array}{c}13.44 \\
-1529.65 \\
1163.51 \\
368.41 \\
-637.83 \\
622.12 \\
\end{array}$ & $\begin{array}{c}120226.3 \\
12743.45 \\
75958.15 \\
58594.75 \\
15871.05 \\
96122.4 \\
\end{array}$ \\
\hline $\begin{array}{l}6.7 \% \\
13.98 \%\end{array}$ & over in 2015 & $\begin{array}{l}\text { Sea water } \\
\text { Lake water } \\
\text { Floating } \\
\text { vegetation } \\
\text { Islands } \\
\text { Sand bar and } \\
\text { urban } \\
\text { Agriculture }\end{array}$ \\
\hline
\end{tabular}

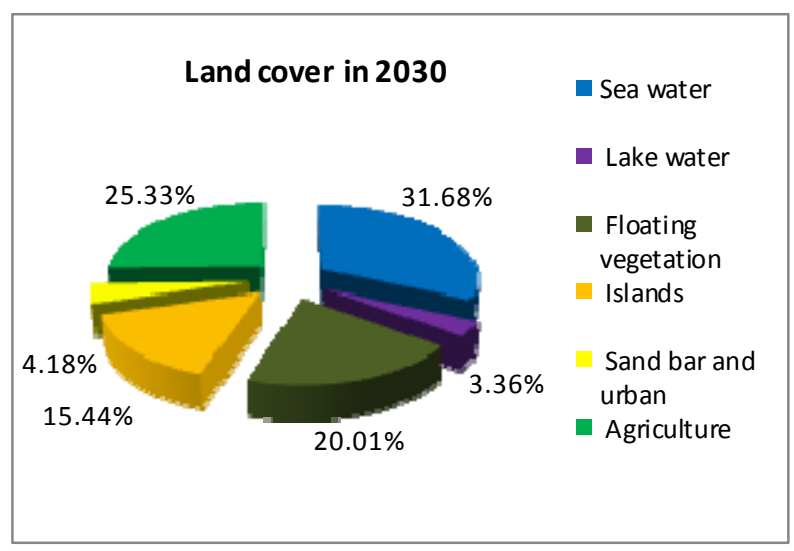

Fig. 6. Land cover for the study area in 2015 and 2030

\section{Conclusion}

This research highlighted the impact of the growth of the floating vegetation on decreasing the water body of Manzala Lake. Both remote sensing and geographic information system are used to extract and analyze the needed information. Maximum likelihood supervised classification was applied to subsets of the Landsat Thematic Mapper (TM), Enhanced The sematic Mapper Plus (ETM+) and Operational Land Imager and Thermal Infrared Sensor (OLI/TIRS) images acquired on 1984, 1998, and 2015, respectively to monitor changes in Manzala Lake. The overall accuracy for the classification of the captured images in 1984, 1998 and 2015 are $83.67 \%, 86.33 \%$, and $89.33 \%$ respectively. The analysis indicated that the water body of the lake has a decreasing trend while the floating vegetation has an increasing trend due to discharging of the agriculture wastes and municipal wastes in the lake without adequate treatment. Over the entire period of the analysis (from 1984 to 2015) water bodies of the lake decreased by $47,419.1$ ha as $57.06 \%$, while floating vegetation and Islands area increased mostly by the same amount. The water body will decrease by $84.67 \%(70,363.85 \mathrm{ha})$ in the year 2030 if the same trend of growth of the floating vegetation continues over the next 15 years which makes the water body of the lake unsustainable. This may lead to a variety of negative environmental impacts and may endanger the ecosystems in the area of the lake. The authors recommend that a proper treatment of the waste should take place and a regular maintenance and cleaning of the lake should be done keeping in mind the economic value of the floating vegetation.

\section{Acknowledgements}

The first author would like to thank Egyptian Ministry of Higher Education (MoHE) for granting him the Ph.D. scholarship. Also, thanks and appreciation is due to Egypt-Japan University of Science and Technology (E-JUST) and JICA for their support and for offering the tools needed for this research.

\section{References}

[1] I. Hegazy and M. Kaloop, "Monitoring urban growth and land use change detection with GIS and remote sensing 
techniques in Daqahlia governorate Egypt", International Journal of Sustainable Built Environment, 2015.

[2] C. Petit, T. Scudder and E. Lambin, "Quantifying processes of land-cover change by remote sensing: resettlement and rapid land-cover changes in south-eastern Zambia", International Journal of Remote Sensing 22(11): 34353456, 2001

[3] L. Sohl and B. Sohl, "Land-Use change in the Atlantic coastal pine barrens ecoregion", geographical review, 102(2), pp180-201, 2012.

[4] B. Haack, " Monitoring wetland changes with remote sensing: an East African example ", Environ. Manage. 20, 411-419, 1996.

[5] N. Donia and M. Hussein, "Eutrophication assessment of lake manzala using GIS techniques", eighth International Water Technology Conference, IWTC 2004, Alexandria, Egypt.

[6] A. Singh, "Digital change detection techniques using remotely-sensed data", International Journal of Remote Sensing, 10(6), pp 989-1003, 1989.

[7] R. Lunetta and L. Worthy, "Land cover Change Detection using Multi-Temporal MODIS NDVI Data", Remote Sensing of Environment, 105, pp 142-154, 2006.
[8] B. Turner, W. Meyer and D. Skole, "Global land-use/landcover change: towards an integrated study", Ambio, 23(1), pp.91-95, 1994.

[9] E. Lambin, H. Geist and E. Lepers, "Dynamics of land-use and land-cover change in tropical regions", Annual Review of Environment and Resources, 28, pp. 205-241, 2003.

[10]R. Anderson, T. Roach and E. Witmer, "A land use and land cover classification system for use with remote sensing data", Geological Survey Professional, p964, 1976.

[11]H. Hossen and F. Ali, "Practical aspects of using highresolution satellite images for map updating", Al-Azhar Engineering International Conference(AEIC), Cairo, Egypt, December 25-27, 2012.

[12]Y. Mostafa, "Comparison of Land cover change detection methods using SPOT images", Master of Science, Department of Civil Engineering, Assiut University, Egypt, 2006.

[13]M. Story and R. Congalton, "Accuracy assessment: A user's perspective", Photogrammetric Engineering \& Remote Sensing. Vol. 52, no 3, pp. 629-643, 1986.

[14]J. Jensen, "Introductory digital image processing: A Remote Sensing Perspective", Second Edition, New Jersey, U.S.A, 1996. 